\title{
The China Review and Chinese Novel Studies
}

\author{
$\mathrm{Xin} \mathrm{Hu}^{1, *}$ \\ ${ }^{1}$ College of Chinese Language and Literature, Hunan University, Changsha, Hunan, China \\ "Corresponding author. Email: huxin2026@163.com
}

\begin{abstract}
The China Review is an English publication founded in Hong Kong in the late 19th century which covers literature, culture, history, society and other aspects of China. The paper explores the reviews and the research articles on Chinese novels published in The China Review so as to study the westerners' comprehension and cognition of Chinese novels and Chinese literature at the end of the 19th century. What's more, the role and significance of The China Review in disseminating Chinese novel to the English-speaking world in the history of Chinese and foreign literary exchange will be explored as well. Through textual analysis, the paper finds that the contributors of The China Review have conducted some in-depth discussions on the origin, classification, characterization, plot pattern and other aspects of Chinese novel. Although The China Review is not a specialized academic journal on Chinese literature, the research articles on the study of Chinese novels published by the periodical can be played as a supplementary role to the professional study in this field.
\end{abstract}

\section{Keywords: The China Review, Chinese novel studies, Chinese and Western literary exchange}

\section{INTRODUCTION}

As an English publication for English readers, The China Review, or Notes and Queries on the Far East, the main content is to introduce and study China. Over the past 29 years, The China Review has carried on the detailed description and researches for China with regard to language and literature, science and technology, art, customs, history, geography, etc. which is regarded as "the first sinology periodical in the true sense of the Western world" [1]. In The China Review, there are more than 70 articles on the translation and research of Chinese novel as well as disquisitions on the study of Chinese novel. These articles on Chinese novel published in The China Review formed part of western research achievements on Chinese literature in the 19th century. The paper intends to explore the westerners' comprehension and cognition of Chinese novel and Chinese literature in the late 19th century from three aspects: the publication background of The China Review, the contributors and the researches on Chinese novel of The China Review, thus to explore the significance that The China Review spread Chinese novels in English-speaking world in the history of Chinese and Western literary exchange.

\section{THE PUBLICATION BACKGROUND OF THE CHINA REVIEW}

Founded in Hong Kong in July 1872 and ceased publication in June 1901, The China Review was published 25 volumes with 150 issues in total. There are 6 issues per volume, each issue has a consecutive page number, and the length of each issue is about 60 pages. Except for Volume XII (519 pages) and Volume XXIV (296 pages), each volume ranges from 300 to 400 pages.

The first editor of The China Review was a British named N. B. Dennys and the second editor was E. J. Eitel, a German. A. Falconer served as chief editor from 1882 to 1885 , and James Dyer Ball was the last editor of The China Review from 1900 to 1901 .

The China Review mainly contains six columns: Articles, Notes and Queries, Notices of New Books, Collectanea Bibliographica, Books Wanted, Exchanges, \&c. and To Contributors. The periodical mainly consists of "Articles", including essays, book reviews and translation. The column of "Notices of New Books" mainly reports the major academic activities and recently published works and articles in the sinology field, especially the contents of China studies in newly published sinology books and related periodicals. In April 1876, the fourth volume, the fifth issue, added the column of "Collectanea Bibliographica", collecting 
academic achievements related to Chinese studies that sinologists were interested in.

The China Review is co-published by China Mail Office in Hong Kong, Trubner \& Co. in London and Kelly \& Walsh Ltd. In addition to Hong Kong, the periodical is distributed in Shanghai, London, Singapore and other places. Based in Hong Kong, The China Review's distribution covers the coastal port cities of China, Southeast Asia, Europe and the emerging Englishspeaking world the United States and Australia [2], enabling English readers to know and understand China through this periodical.

The content of The China Review covers a wide range. The topics explicitly mentioned in the "Introductory" to the periodical include "Arts and Sciences, Ethnology, Folklore, Geography, History, Literature, Mythology, Manners and Customs, Natural History, Religion, etc." [3], which contains wealth social information about modern China. A total of 945 articles have been published in The China Review, covering Chinese literature, religion, law and many other fields. Among them, there are substantial numbers of articles on Chinese literature, Chinese novels in particular. There are introductions and translations of Chinese classical novels, as well as the research articles on Chinese novels, such as The Adventures of a Chinese Giant, Tales from The Liao Chai Chih Yi, San Kuo Chih, A Visit to The Country of Gentlemen, A Chinese Romance, and so forth, along with An Hour With a Chinese Romance, Chinese Fiction and other research articles discuss the literary value of Chinese novels, comment on the characterization of Chinese novels, and introduce the origin, classification, moral aesthetics and other aspects of Chinese novels.

\section{THE PLURALISTIC WRITING CONTRIBUTORS}

Although the missionaries who came to China in the 18th century "introduced and translated a large number of Chinese classics, they seldom translated Chinese novels due to the limitation of missionary purposes and the influence of the Chinese orthodox literature view" [4]. In addition, the translation of Chinese novels by westerners in the 18th and 19th centuries were mostly based on the novels introduced and translated by predecessors, retranslated the novel texts, or translated according to foreign language translations. To English people, much of the early knowledge about Chinese novels came from the English translations of French versions. As European nationals in China "turned their attention to the more attractive studies the Chinese light literature in their spare time, including drama, novel, legend and poetry" [5], as a consequence, the number of Chinese novels translated into English began to increased rapidly at the beginning of the second half of the 19th century.

In the 19th century, Western sinology research has already passed through the stage of travel notes sinology, and it was shifting from missionary sinology to professional sinology, and the researchers engaged in sinology expanded from missionaries to people in many other fields. The contributors of The China Review shows this characteristic. There are a total of 405 Byliner of The China Review [6]. The contributors are mainly British, Americans and Germans account for a certain proportion. A small number of French, Swiss and Chinese authors are also included, as well. As far as the editors of The China Review are concerned, the first editor in chief, N. B. Dennys, was a British consular officer and journalist. E. J. Eitel, the second editor in chief, was a German missionary. During his tenure as editor in chief of The China Review, he left the church and turned to serve in the Hong Kong government. The other two editors in chief of The China Review are A. Falconer, the principal of Hong Kong Central School, and James Dyer Ball, has long served in the Supreme Court of the United Kingdom in Hong Kong. As for the contributors on Chinese novels in The China Review, there are 20 authors carried byline, occupation as customs staffs, Hong Kong government staffs, businessmen, journalists, and the like. Only one was a missionary by profession. The main contributors are: F. H. Balfour, chief commentator of British press, British customs staffs G. Taylor, C. H. Brewitt-Taylor, and G. C. Stent, British diplomats R. W. Hurst, C. F. R. Allen, and E. L. Oxenham, and others.

The contributors of The China Review "study Chinese literature for its own reasons, so it is natural for them to introduce Chinese literature to their compatriots through the intermediary means of translation" [7]. The contributors of Chinese novels in The China Review have lived in China for a long time, and possessed a certain level of Chinese language. Moreover, compared with scholars and sinologists in Europe, they have access to more Chinese novels, and thus they were often able to find many works that were not known to Europeans before. In addition, with the development of sinology, which "aroused more Westerners' attention to Chinese novels" [8], and Westerners have new views on Chinese novels as well. These novels "present readers with a complete and exquisite picture of Chinese life", and along with the ever-increasing connections between the East and the West, "it is also extremely important for Westerners to understand China through Chinese literature" [7]. As a result, there are not only a large number of Chinese novels published in The China Review, several of which have been 
introduced and translated into the English-speaking world for the first time. For instance, The Young Prodigy, serialized in Volume II, issues 1 to 5, between 1873 and 1874. Scraps from Chinese Mythology, which was serialized in nine times between 1881 and 1884. The Tang Hou Chi: A Modern Chinese Novel serialized in Volumes V to VI from 1877 to 1878 and other novels are the earliest Western language translations known so far.

The Chinese novels published in The China Review are mainly historical novels, scholar beauty novels, novels of gods and spirits, and encyclopedic fictions. Different from the utilitarian nature of missionaries and the academic nature of professional sinologists, these translated works of European nationals in China with diverse identities reflect the role of Chinese novels as entertainment for readers, at the same time, it present the characteristics of combining entertainment with specialty. Their translations may not be rigorous and in line with the original texts, though, their introductions of Chinese novels can bring the readers of English-speaking world into contact with Chinese novels they have never read before. The Chinese novels in The China Review "providing westerners with direct samples of Chinese classical novels and greatly enriching the contents of Chinese classical novels translated into Western languages" [9], thereby opening up the translation and research of Chinese novels. For these European nationals in China, the introduction and translation of the Chinese novels made them the first translators to introduce these Chinese works to the English-speaking world.

\section{COMMENTS AND RESEARCHES ON CHINESE NOVELS}

Compared with the results of professional sinologists in the translation and research of Chinese novels, there is still a certain gap between the contributors of The China Review and the professionals. The contributors of The China Review have also conducted some in-depth discussions as far as possible, nevertheless. Among the articles on the introduction and translation of Chinese novels published in The China Review, the comments on Chinese novels in the preface and notes in the text which introduce the author of the translated Chinese novels and the synopsis of the novels, elaborate the motivation of selecting the translated works or comment on the plots and characters in the novels. To sum up, they are mainly consist of the following contents and viewpoints:

The first is the background and time of the Chinese novel's origin. The article A Legend of the T'ang Dynasty, published in the sixth issue of Volume V of The China Review, discusses the origin of Chinese novels in the preface. The article suggests that Chinese novels originated from the period between the eighth and tenth centuries. At that time, China was unified and stable with strong national strength, and other Asiatic nations sent their envoys. Emperors encouraged literature production, thereupon "during the middle period of the Tang dynasty, to grow up a class of romantic tales in which the kinship of ideas with those that distinguish the products of Arabian genius is too marked to be ignored" [10]. Whereafter, "it was at this period that the drama began to flourish, and the germs of the modern novelist's art made their first appearance" [10].

The second is the classification of Chinese novel. Alfred Lister divides Chinese novels into two categories: the historical romance and the tales of everyday domestic life [11]. The novel Romance of the Three Kingdoms serves as the typical representative of the former, which is known as "the romance of all romance" [12]. However, Lister appreciated tales of everyday domestic life, the novel Yü Chiao $L i$ in particular, which he called "the best Chinese novel" [11]. According to E. W. Thwing, the two most important categories of Chinese novels to be historical novels and romances, and pointed out that "the romance is not usually so long as the historical novel, there is more of conversation and description, and the style in some of the books is alcolloquial" [13]. And from the perspective of J. Dyer Ball, "the historic novel is much prized" [14].

The third is characterization of Chinese novel. In J. Dyer Ball's article published in the third issue of Volume XXV of The China Review in 1900, he argued that Chinese novel followed "a finished sketch in black and white": "The villains are as black as black can be, and form the deepest background to throw into relief the virtuous hero and heroine and their friends, helpers, and well wishers. The hero is a paragon of excellence, physically, mentally, and morally" [15]. E. L. Oxenham, in his preface to The Tang Hou Chi, published in the sixth issue of Volume V, stated that The Tang Hou Chi is

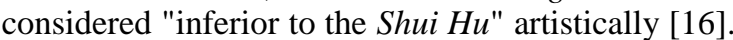
Nonetheless, compared with Shui Hu, The Tang Hou Chi created some vivid female images, which to some extent overturns the stereotype of the inferior status of Chinese women. The translator aimed to leave his readers "to make acquaintance with Ch'en Hsi-chen, priest, warrior, general and scholar; with loyal and patriotic officers, as Yun T'een-piao and Chung Shih-tao; with selfish intriguers and vicious men and ministers, like Kaochiu and Ts'ai-ching; with brigands pretending to be patriotic and patriots acting the part of brigand; and with those incomparable specimens of the lovelier sex 'the Miss Supremely Beautiful' and the 'Miss Intelligent'" [17]. E. W. Thwing deemed stereotype 
of characters in the Chinese novels. Characters, "the bad are always bad, and the good invariably, supremely good" in Chinese novels [13].

The fourth is plot pattern of Chinese novel. Not just the characterization, E. W. Thwing held that plot pattern of Chinese novels had come to be a fixed stereotype of narration. As for plot, "there is often much sameness and repetition", and the ending of these stories "tell us of a happy union" [18]. Alfred Lister held a similar opinion, in Chinese novels "when the same thing with very slight variations is repeated an indefinite number of times it becomes tiresome, and drives the reader to the end of the book to come in at the happy marriage just for the sake of form" [11]. J. Dyer Ball pointed out, Chinese novels such as The Fortunate Union, the novelist cleared away all difficulties "by his consummate skill in the unravelling of the plots and intrigues against hero and heroine, and again of course, all comes well at the end" [15].

In these articles published in The China Review, the commentary on Chinese novels varies in length, reflecting the attitudes and perceptions of Westerners towards Chinese novels in the late 19th century. A general survey of these comments on Chinese novels reveals that they basically no longer treat Chinese novels as samples of Chinese religious beliefs and moral concepts, but begin to examine them from the perspective of literary appreciation. This is reflected in the comments on Yü Chiao Li.

In "An Hour With A Chinese Romance", Alfred Lister discussed the story types, moral aesthetics, themes, characters and other aspects of Chinese novels, and explained the related issues of Chinese literature reading and research, such as the reason why western readers read and even appreciate Chinese literature, whether Chinese literature has the real spiritual power, artistic power and aesthetic power to attract and move western readers. As far as Lister's concerned, Yü Chiao Li is "the best Chinese novel" [11]. Compared with The Dream of the Red Chamber which is regarded as "the head of Seric fiction" [11], Yü Chiao Li possesses a more cohesive structure. Furthermore, Yü Chiao Li portrayed a large number of characters. Lister held that the work is worthy for western students to read and learn Chinese and Chinese literature in detail, because it was "masterly book which will bear reading again and again because you do not read it only for the story" [19]. Significantly, Lister mentioned the standard of "sweetness and light" in Culture and Anarchy by Matthew Arnold, the 19th century British literary and cultural critic in his comments on Yü Chiao Li [20]. In Lister's view, Yü Chiao $L i$ was a fine novel to implement this standard. Using the views of British literary critics at that time to interpret Chinese literature texts was one of the characteristics of Chinese novel researches in The China Review, and has an enlightening effect on the research methods of Chinese literature in the West during the late 19th century.

An article by E. W. Thwing in The China Review entitled "Chinese Fiction" is a special article on Chinese classical novels. The article, serialized in two installments, explores the significance and value of Chinese novels from the perspective of comparative culture. Thwing opined that Chinese novels were of significance for westerners, "more real knowledge of Chinese can be obtained from such sources than any other" [21]. In Chinese novels "you find here common writing style of the people, many of their every-day ideas, their social customs, a good view of their government, in fact pictures of Chinese life past and present" [21]. In the article, there was a quote from sinologist Alexander Wylie's commentary on the importance of novel: "The novels and romances of the Chinese are too important as a class to be overlooked. The insight they give to the national manners and customs of various ages, the specimens they furnish of an ever-changing language, the fact of this being the only channel through which a large portion of the people gain their knowledge of history", the stories "although full of fancy, are often very true to life" [21]. Conspicuously, when Thwing was talking about the value of Chinese novels, he attached importance to the functional value of Chinese novels, but did not pay enough attention to the aesthetic value of Chinese novels. The reason was that European nationals in China laid importance on investigating and obtaining information about Chinese people's living conditions, social conditions, spiritual and moral conditions.

In addition, in the article, Thwing listed in detail the Chinese novels introduced and translated in The China Review, pointing out that the Chinese novels introduced to the West are a small fraction of the vast number of novels that exist in China. Accordingly, he listed a catalog of Chinese novels that need to be taken into account by Sinologists in the future, such as The Four Wonderful Books, The Plum-tree that Blossomed Twice, The Story of a Remarkable Youth etc., and introduced five Chinese novels: The Account of the Three Kingdoms, A Pleasing Love Story, The Two Fair Cousins, Two Young Literary Girls, and An Account of the River Robbers. In this catalog of Chinese novels, however, Narratives of Distinguished Women, The Twenty Four Dynasties are listed as well, demonstrating the cognitive deviation of western readers towards Chinese novels. 


\section{CONCLUSION}

The translation and research on Chinese novels in The China Review is rich and multi-layered. It not only introduces and translates dozens of Chinese novels of different themes, but also reviews and studies the Chinese novels of the 19th century that attracted the attention of the West, showing its keen insight in the communication between Chinese and Western literature and culture.

The identities of editors and contributors of The China Review are diversified, and most of them with good educational background, which reflects the openness of the periodical on the one hand; on the other hand, ensures the quality of the translation of Chinese novels published to a certain extent, as well as the diversity of research views on Chinese novels. At the same time, the religiousness of the periodical has been decreased, and the professionalism has been enhanced, effectively realized the communication between Chinese and Western literature and culture in the translation and research of Chinese novels. The China Review, however, is a comprehensive English journal rather than a specialized academic journal on Chinese literature. Although the contributors of The China Review try their best to carry out some in-depth discussions research in Chinese novels, inevitably there are some errors exist in the disquisitions about Chinese novels published in it. In this regard, the translation and research on Chinese novels of The China Review is still some way off compared to the works of professional sinologists. Nevertheless, in the study of Chinese literature in the West in the 19th century, the disquisitions on the study of Chinese novels published by The China Review can be played as a supplementary role to the professional study in this field. As such, the publication of Chinese novels in The China Review as well as the commentary and research on Chinese novels, are of significance to the early dissemination of Chinese novels in the Englishspeaking world.

\section{References}

[1] Wang Guoqiang, The China Review (1872-1901) and Western Sinology. Shanghai: Shanghai Bookstore Publishing House, 2010, pp. 263.

[2] Wang Guoqiang, The China Review (1872-1901) and Western Sinology. Shanghai: Shanghai Bookstore Publishing House, 2010, pp. 63.

[3] N.B. Dennys, "Introductory," The China Review. Hongkong, vol. I, pp. 1, July 1872.

[4] Zhang Xiping, Introduction to Sinology Study. Beijing: Foreign Language Teaching and Research Press, 2005, pp. 302.

[5] J.F. Davis, Chinese Miscellaneous: A Collection of Essays and Notes. London: John Murray, 1865, pp. 55.
[6] Wang Guoqiang, The China Review (1872-1901) and Western Sinology. Shanghai: Shanghai Bookstore Publishing House, 2010, pp. 66.

[7] M.G. Mason, Western Concepts of China and the Chinese 1840-1876. Beijing: Zhonghua Book Company, 2006, pp. 42.

[8] Song Lijuan, The Introduction of Chinese Learning to the West and the Early Translations of Chinese Classical Novels (1735-1911). Shanghai: Shanghai Classics Publishing House, 2017, pp. 426.

[9] Song Lijuan, The Introduction of Chinese Learning to the West and the Early Translations of Chinese Classical Novels (1735-1911). Shanghai: Shanghai Classics Publishing House, 2017, pp. 282.

[10] N.B. Dennys, "A Legend of the T'ang Dynasty," The China Review. Hongkong, vol. V, pp. 344, May 1877.

[11] A. Lister, "An Hour with a Chinese Romance," The China Review. Hongkong, vol. I, pp. 287, April 1873.

[12] A. Lister, "An Hour with a Chinese Romance," The China Review. Hongkong, vol. I, pp. 286, April 1873.

[13] E.W. Thwing, "Chinese Fiction," The China Review. Hongkong, vol. XXII, pp. 760, June 1897.

[14] J.D. Ball, "Professor Douglas's Translation of the Fortunate Union," The China Review. Hongkong, vol. XXV, pp. 143, December 1900.

[15] J.D. Ball, "Professor Douglas's Translation of the Fortunate Union," The China Review. Hongkong, vol. XXV, pp. 144, December 1900

[16] E.L. Oxenham, "The Tang Hou Chi: A Modern Chinese Novel," The China Review. Hongkong, vol. V, pp. 367, May 1877.

[17] E.L. Oxenham, "The Tang Hou Chi: A Modern Chinese Novel," The China Review. Hongkong, vol. V, pp. 368 , May 1877

[18] E.W. Thwing, "Chinese Fiction," The China Review. Hongkong, vol. XXII, pp. 763, June 1897.

[19] A. Lister, "An Hour with a Chinese Romance," The China Review. Hongkong, vol. I, pp. 291, April 1873.

[20] A. Lister, "An Hour with a Chinese Romance," The China Review. Hongkong, vol. I, pp. 288, April 1873.

[21] E.W. Thwing, "Chinese Fiction," The China Review. Hongkong, vol. XXII, pp. 759, June 1897. 